Cilt / Volume: 2

Sayı / Issue: 2

Kiş/ Winter 2021

S e l çu ü niversitesi

İslami Ílimler Fakültesi Dergisi

\title{
Dinî Açıdan Olumlu ve Olumsuz Yönleriyle Organ Nakli
}

Faruk Beşer

Prof. Dr., Marmara Üniversitesi İlahiyat Fakültesi Emekli Öğretim Üyesi Professor, Retired Faculty Member, Maramra Univ. Faculty of Theology, İstanbul, Türkiye

○farukbeser@gmail.com

Mülâkat

Interview

Faruk Beşer. "Dinî Açıdan Olumlu ve Olumsuz Yönleriyle Organ Nakli”. (Mülâkat: Süleyman Şahin). Tevilat 2/2 (2021), 305-312.

doi https://doi.org/10.53352/tevilat.1048341

1. Hocam giriş mahiyetinde, İslam hukukunun güncel meselelere çözüm üretmede benimsediği yöntemlerden kısaca bahsedebilir misiniz?

Dinin aslı Allah'ın gönderdiği vahiy, yani Kuranı Kerim'dir. Bu vahyi biz öncelikle Hz. Peygamber'in onu canlı olarak yaşaması demek olan sünnet örneği ile anlayabiliriz. Sonra icma ve içtihatlar devreye girer. En önemli içtihat şekli kıyastır. Bir üst delil varken alttaki delile itibar edilmez. Bu dinî bilgi meratibin hiçbiriyle hükmü anlaşılamayan bir meselede önce kamunun, sonra da bireyin maslahatı, diğer bir ifade ile, kâr-zarar hesaplaması esas alınır.

Maslahat, dinin asıl gayesi olan beș temel esasın korunmasından ibarettir: Yaşama hakkı (can), Mülkiyet hakkı (mal), Neslin korunması (ırz), Aklın korunması (Düşünce özgürlüğü) ve Dinin korunması (Din özgürlügü). Hükümler bu beș temel esası oluşturmak, korumak ya da bunlara gelecek zararı önlemek için konmuştur. 
$\mathrm{Bu}$ beş temel esasa zarar veren, ya da faydası olsa bile zararı faydasından çok olan şeyler haramdır.

Sonradan ortaya çıkan bir mesele, eğer sağlığı ilgilendiriyorsa, zararlı olması halinde sakıncalı, değilse "eşyada aslolan mubahlıktır" kuralı gereği helal ve meşru kabul edilir.

\section{Bu bağlamda organ naklinin fıkhi hükmü hangi yöntemlerle elde edilebilir?}

Bu deliller sıralamasına baktığımızda organ nakli konusunda kıyasla da olsa kesin bir hükme varabileceğimiz açık ve doğrudan dinî delillerin bulunmadığını görürüz. 0 halde dinin genel prensiplerinden ve korumayı hedeflediği temel haklardan ve maslahatlardan hareket etmek zorundayı.

Sözünü ettiğimiz beș temel esasın hepsinin insan için söz konusu edildiği açıtır. $O$ halde bütün hükümler insanın, değerini Allah'tan alan/mükerrem bir varlık olduğu düşüncesine dayanır. Bunun anlaşılmasıyla ancak, insan neden sağlıklı olmalıdır ve neden mümkünse biraz daha fazla yaşamalıdır, sorusunun cevabı anlaşılmış olabilir.

Bilindiği gibi "yerde ve gökte olan her şey insanın emrine verilmiş, insan için yaratılmıştır" (el-Câsiye 45/13). Bunun karşılığında ondan istenen şey, Allah'ı tanıması ve O'na kulluk etmesi ve dünyayı buna göre imar etmesidir. Bu görevini tam yapabilmesi için insanın sağlıklı olması gerekir. İnsan kendi bedeninin mutlak sahibi değildir. Bedeni ona emanettir, ona iyi bakmalı ve hasara uğratmadan onu sahibine teslim etmelidir. Bu sebepledir ki, insan kendi hayatına bile istediği zaman son veremez. İntihar ve intihar anlamındaki ötenazi haramdir.

"Bir insanı öldürmek bütün insanları öldürmek gibi büyük günahtır. Bir insanı diriltmek/ölümünü engellemek de bütün insanları diriltmek gibi büyük sevaptır" (el-Mâide 5/32).

Rasûlullah (s.a.v.) tedaviye sanıldığından da fazla değer vermiştir. Hatta meselenin üzerinde duranlar İslam'da tedavi konusu kadar hemen her çareye müsaade edilebilen bir başka konunun olmadığını söylerler. Aslında her hastalığın helal bir tedavi yolu vardır. Haramda çare aramamak esastır. Ama helal olan tedavi yolu bulunamamışsa ortada bir zaruret var demektir ve zaruret sebebiyle bazen sakıncalı olan şeyler de yapılabilir. Bir taraftan da helal tedavi yöntemlerini aramak müminler üzerine hem farz-ı kifâye düzeyinde bir görevdir hem de bir ibadettir. Müminlerin tedaviyi ve ilacı başkalarından temin etme yoluna gitmeleri görevlerini ihmal etmekte oldukları anlamına gelir.

Ancak her türlü tedavi yönteminin dinin temel prensipleriyle çatışmaması, insanın şerefini zedelememesi ve onu sıradanlaştırmaması esastır.

\section{3. İslam hukukçularının organ nakli hususundaki yaklaşımları nasıldır?}

Konu hakkında 1970'li yıllardan beri İslam dünyasında pek çok tez ve araştırma yapılmıştır. İslam fikıhçıları ya da "İslam Fıkıh Konseyi" gibi kuruluşlar 
konu hakkında tartışmalı oturumlar gerçekleştirmiş, kararlar vermişlerdir. Kararların ortak noktası, organ naklinin bazı şartlar ve sınırlamalarla caiz görüleceğidir.

Bu cevaz şöyle detaylandırılır:

- Bir insanın kendi organları arasında tedavi amaçlı nakil yapılması caizdir.

- Kendini yenileyen kan, doku ve ilik gibi maddelerin yine tedavi amaçlı olmak üzere bir başkasına verilmesi caizdir.

- Bir parçası verildiğinde kalanı kısmen de olsa görevini yapabilen bir organın, bunu almadığı takdirde bu fonksiyonu bütünüyle yitirecek olan birisine verilmesi caizdir. Böbrek ve kornea nakli böyledir. Çünkü iki böbreği de iflas etmiş olan birisinin yaşaması mümkün değildir, ama bir böbreğini veren birisi tek böbrekle yaşayabilir, diğer insan da ölümden kurtulmuş olur.

- Verildiği takdirde verenin ölümüne sebep olacak bir organın verilmesi ister kendi rızası ile ister başka bir yolla olsun, caiz değildir. Çünkü bu durum, kendi isteğiyle olması halinde intihar, başka bir yolla olması halinde ise bir cana kıymadır ki, her ikisi de haramdır.

- Ölüme sebep olmasa dahi bir organın verilmesi, verilmemesinden, toplamda daha çok zarara sebep oluyorsa bu da caiz değildir. Mesela sadece bir böbreği sakat olan birisine sağlıklı birisinin bir böbreğini vermesi böyledir.

- Ölenin önceden bağışlaması, ya da varislerinin veya bunların hiçbiri yoksa velayeti sebebiyle yönetimin müsaade etmesi halinde bir ölüden de organ alınabilir. Ancak burada da hayati bir zaruretin bulunmuș olması gerekir. Yani organ alacak olan bunu almadığı takdirde yaşayamayacak durumda olmalıdır.

Fakat bazı âlimlerin, velinin velayetine sahip olduğu kişinin aleyhine olacak durumlarda tasarruf hakkının olmadığı hükmünden hareketle, bizzat kendi izni bulunmayan müteveffadan velisinin izniyle organ alınamayacağı kanaatinde oldukları da bilinmelidir.

- Mahremiyeti ilgilendiren durumlarda, yapılabilmesi mümkünse, mesela cinsel organ ya da rahim nakli caiz görülmemiștir. Ancak diğerleri caiz ise bunu istisna etmenin ikna edici bir delili yoktur. Ya da diğerleri de caiz olmamalıdır. Bunda muhtemelen neslin muhafazası prensibi hedeflenmiş olabilir.

- Nakli yapılacak organ bir protezle ya da bir başka hayvandan alınabilecek bir organla karşılanabilecekse insandan organ alınması caiz olmaz. Hayvanlardan da sadece her hâlükârda pis sayılan domuz istisna edilmiștir.

- Doğrudan İslam'ın temel naslarından alınmış olmasa bile bir içtihat olarak insanın hiçbir organının parayla satılmasının caiz olamayacağı da yine ittifakla söylenmiştir.

\section{4. İslam hukukçuları organ naklinin hükmü konusunda hangi delilleri esas almaktadır?}

Günümüzdeki fakihlerin çoğunluğu bu hükümleri verirken aşağıdaki delillere tutunmaktadırlar:

1. Sözünü ettiğimiz, "bir insanı diriltmek, yani ölümünü engellemek bütün insanları diriltmek gibi büyük bir sevaptır" anlamındaki ayet konunun en belirleyici delili olarak görülür. Ancak bu ayetin organ nakline açıcça değil, 
dolaylı bir cevaz verdiği bellidir. Birinin hayatına belli bir süre katarken, diğerininkinden eksilmeye sebep olmak açık bir maslahat sayılmamalıdır.

2. İslam'daki "zaruretler mahzurlu olan șeyleri mubah kllar" kaidesi de konu hakkında tutunulan en önemli delillerden biridir. Ama bunun yanında da "zaruretler kendi miktarınca takdir olunur" kaidesi de vardır. Zaruret prensibi de ayrıca bütün alternatiflerin devreye sokulmasından sonra düşünülecek bir çare olabilir.

3. İslam'ın tedaviye vurgu yapması da hükme bir destek olarak dile getirilir. Yukarıda değindiğimiz gibi, bu doğrudur ancak bu tedavi için de insanın kerametini zedelemeyen ve haram yolla olmayan bir tedavi olması ön şartı vardır. Canlı olsun kadavra olsun, organı alınan insan mekanik bir varlık düzeyine indirgenmiş sayılamaz mı sorusunun ikna edici cevabının bulunması gerekir.

4. Bir diğer delil "ibâha-ı asliyye" dediğimiz genel kuraldır. Bunun açılımı şudur: Önceden de değindiğimiz gibi, eşyada aslolan mubah olmasıdır. Organ naklinin haram olduğuna dair bir delil bulunamıyorsa helal olmalıdır denir. Ama bu delilin doğruluğu da ancak, başka bir sakıncanın tespit edilememesi halinde söz konusu edilebilir. Organ naklinin faydalı yönleri bugün bilinebildiği halde, zamanla ortaya çıkacak zararlı yönleri henüz tam biliniyor değildir. On altıncı asırda İslam dünyasında sigara yaygınlaştığı zaman, fukahanın verdiği hüküm şu idi: Sigaranın zararı bilinmemektedir, eşyada aslolan da helal olmasıdır, o halde sigara helaldir. Oysa zamanla sigarada yüzlerce zararın bulunduğu anlaşılmış oldu ve biz bugün artık kuşku duymadan sigaranın haram olduğunu söyleyebiliyoruz.

5. Konu için şöyle bir dayanak daha zikredilebilir: İslam "îsâr"ı övmüştür. Îsâr, bir müminin, kendisi muhtaç olsa bile kardeşini kendine tercih etmesidir, fedakârlık demektir. Uhud Savaşında Hz. Peygamber'i korumak için onun etrafında canlı kalkan oluşturan en az altı sahâbî kendilerini ona yöneltilen oklara hedef yapmış ve âdeta bile bile şehadeti tercih etmişler ve yaptıkları da kınanmamıştır. 0 halde bir müminin kardeşi için organını bağışlama gibi bir fedakârlıkta bulunması güzel bir haslettir. Ancak bu da organ naklinin cevazına açık bir delil teşkil etmez. İslam'ın genel değerleri için kendini feda etmekle, birisine bir organ bağışlamak aynı şey olamaz.

Organ nakli uygulamasına açıkça temel teşkil etmese de İslam tarihinde konuya ışık tutacak bazı ilginç hükümler konuyu izah sadedinde zikredilir. Mesela:

Rasûlullah (s.a.v.), "Bir ölünün kemiğini kırmak onu diri iken kırmak gibidir" (Ebu Davud, “Cenâiz", 64; Nevevî, "el-Mecmû’”, V, 300) buyurur. Bu hadisi şerif ölüden organ alma meselesiyle ilişkilendirilebilir.

Fıkıh kitaplarında farazi fıkı dediğimiz varsayımlar üzerinde durulurken ilginç örnekler verilir. Bunlardan birisi şudur: Bir yerde mahsur kalan birden çok insan açlıktan ölmemek için içlerinden birini kesip yiyemezler. Hatta birisi ölmüş olsa bile onun da etini yemeleri caiz olmaz. İnsanın saygınlığı buna manidir, denir.

Bundan olacak ki, İslam geleneğinde tedavi amaçlı domuz ya da koyun kemiği gibi eklentilerden söz edildiği halde, insan parçasından hiç söz edilmemektedir. 
O halde İslam fikhı açısından, günümüzdeki fukahanın verdiği cevaz, olsa olsa şimdilik kaydıyla ve ancak ihtiyatlı bir cevaz olabilir.

\section{Organ nakli hakkında hüküm verilirken konuyla ilgili bilinmesi gereken hususlar nelerdir?}

\section{Hayat ve Ölüm}

Şimdiye kadar verilen hükümler yukarıda zikrettiklerimiz olmakla beraber meseleyi felsefi boyutu ile ele almak işin farklı boyutlarının da olduğunu göstermektedir. Organ naklinin en çok uygulandığı alan ölüden yapılan nakildir. Kadavra ölmüș kabul edilen bir insandır. Ancak ölümü doğru tanımlamak zordur, bu sebeple ölüden organ almak da sanıldığı gibi problemsiz görülmemektedir.

Her şeyden önce insan nedir? Ölüm nedir? Ruh nedir? Ölen insan yokluğa mı gitmektedir? Ölünce insanın değeri ve fonksiyonları sona mı eriyor? Bu ve benzeri sorulara kesin cevaplar verilemeden insanın bütünlüğüne müdahale dinî açıdan her zaman riskli olacaktır.

İnsan ne zaman ölmüş kabul edilecek? Beyin ölümü insanın gerçekten ölmesi demek midir? Bildiğimiz kadarıyla hekimler bile bu konuda görüş birliğine varmış gibi gözüküyorlar, ancak son zamanlarda farklı sesler de çıkmaktadır. Tıpta da beyin ölümünü mutlak ölüm kabul etmeyen eğilimler vardır.

Dini açıdan şöyle düşünülebilir:

İnsan, ruhu ve bedeniyle insandır. Cenin, başlangıçtan itibaren biyolojik olarak canlı iken, ancak ruhun üflenmesiyle insan oluyorsa, beyin ölümünden sonraki canlılığını da ceninde ruhun üflenmesine kadarki canlılığına kıyas edip, onu tam bir insan saymayabilir ve ondan organ almayı caiz görebiliriz. Ama bu da ancak bir ihtimalden ibarettir. Böyle ihtimalli bir bilgi ile bir insanın hayatının sona erdiğine karar vermek mümkün olmamalıdır.

Diğer bir bakışla ruhun bedenden ayrılması da her hâlükârda ölüm sayılabilir mi? Nitekim bir ayeti kerimede uykudaki insanın nefsinin bedeninden ayrıldığı ifade edilir. Gerçi ayette 'ruh' yerine 'nefs' kelimesi kullanılır (ez-Zümer 39/42). Ama ruhla nefs birbirine o kadar yakındır ki, çoğu İslam âlimine göre ikisi de aynı şeydir.

Bir başka değerlendirme ile İslam'da imanın, anlamanın (el-A'râf 7/179) ve akletmenin (el-Hac 22/46) merkezi olarak kalbin gösterilmesi, sanki hayatı kalple ilişkili kılar. Bu durumda da beyin ölümüne mutlak ölüm demek zorlaşır. Kalbin beyin olduğu söylenemez, çünkü bu son ayette onun göğüsteki et parçası olduğu açıkça beyan edilir.

Bir başka açıdan insana 'nefs' denmesine bakılırsa, nefes almayı bir canlılık alameti, almamayı da bir ölüm ölçütü olarak görebiliriz. Ama o takdirde altı haftalığı geçmiş olan cenine canlı muamelesi yapmamamız gerekir ki, bu da doğru değildir.

Ruhtan bize çok az bilgi verildiğinin söylenmesi de meselenin onu zor anlaşılır kılan yönü olsa gerektir. 
Ayrıca bilindiği gibi insan hayatını ilgilendiren hadler konusunda ihtiyatla davranmak asıldır. Hadler en küçük bir şüphe ile kaldırılır. Bir insana öldü hükmünün verilmesi de buna kıyas edilmelidir. Küçük bir ihtimal bu hükme varılmasını engellemelidir.

Her hâlükârda mutlak ölümün başlangıcını tespit edebilmek şimdilik kolay değildir ve bu sadece tıbbın verebileceği bir karar olmamalıdır, işin hukuki ve dini boyutları da vardır.

Ölüden organ alınması, ya da organ bağışı durumunda beyin ölümü kararının iki kişinin, belki de bir kişinin, dudakları arasından çıkması da ayrı bir problemdir. Bir insanın ölüm kararını sadece doktorlara bırakmak doğru olamaz. Çünkü böyle bir kararın yüzde bir de olsa hata yapma, ya da suiistimal edilme ihtimali vardır. Bir insanın hayatı söz konusu olduğunda binde bir ihtimal bile çok büyük bir ihtimaldir.

Kaldı ki, tıpta organ naklini bitkisel hayata doğru genişletme eğilimleri de vardır. Bunun sınırını kimin, nasıl çizeceği henüz belli değildir.

Her şeye rağmen, konunun bütün yönleri hem tıp bilimi hem de İslam fikhı açısından sonlandırılmış ve insani temellere oturtulmuş sayılamaz. Hatta hem tıbbî hem de dînî çevrelerde eğilim, büyük bir zafer ilan etme yerine, tereddütlere ve olumsuzluklara doğru evriliyor gibi gözükmektedir. Her iki kesimde de soru işaretleri ve çekinceler artmaktadır. Her geçen gün işin ciddiye alınmasını gerektiren ahlaki komplikasyonlardan söz edilmektedir.

\section{Bir başka açıdan organ nakli meselesi}

Modern bilim, meseleye harikalar yaratma sevdasıyla bakıyor gibidir. İnsancıllık/hümanizm de bunun reddedilemezliğine payanda yapılmaktadır. Böyle bir bakıș elbette tek taraflı bir bakış olur. Bu insanlığı sadece fizik, hayatı da sadece dünya olarak görmeden ibaret kalır. Parçacı bir bilim anlayışı ile bütünü görmek mümkün olamaz. Böyle bir bilim bir taraftan bir hastayı yedek bir böbrekle üç beş yıl daha yaşatmayı başarı sayarken, diğer taraftan bir düğmeye basmakla on binlerce sağlıklı insanı imha etmenin imkânlarını da ariyor.

Bizce modern tıbbın, organ nakline neden bunca önem veriliyor, sorusuna cevabı ikna edici değildir. Bunu ya bilimsel bir merak ve yaratıcılığa özenme, ya da ölümü ortadan kaldırma düşüncesinden başka bir şeyle anlatmak zordur. Ama bu merak insanlığın sonunu da getirebilir. Hümanist izahlar ise, ancak bunda hiçbir sakıncanın bulunmaması halinde anlamlı olur.

Ünlü fizikçi Stephen Hawking, İngiliz Independent gazetesi için kaleme aldığı bir makalede yapay zekâ teknolojisinin insanlığın son büyük icadı ve sonu olacağı kehanetinde bulunmuştu. Bizce gen teknolojisi de aynı felaketi doğurabilir.

En insani diyebileceğimiz yüz naklini gerçekleştiren bilim adamımızın, "hiç kendime yüz nakli yapılmasını istemezdim" demesi de anlamlıdır.

Diğer yönden, organ naklini yegâne kurtuluş yolu olarak görmek aslında onun alternatiflerinin bulunmasını da geciktirmiş olmaktadır. Bilindiği gibi birkaç yll önce Gaziantep'te bir doktorumuz bir şahsa kendi dokusundan yüz yapmayı başardı. Sanırım bunun caiz olmayacağını söylemek mümkün olamaz. 0 
halde tedaviyi bu yöne kaydırmak daha az riskli bir yöntem olmalıdır. Kök hücre uygulaması bu açıdan önemlidir.

Din söz konusu olduğunda konuya Allah'ın yaratıșına müdahale etme açısından da bakılmalıdır. Bilindiği gibi fitratı ve Allah'ın yaratıştaki kanununu bozmamak dînî olanı anlama konusunda önemli bir ölçüdür. Çünkü Allah'ın fitratında ve sünnetinde değiştirme yapılamaz. Bunu teşvik eden duygu şeytandandır. Çünkü şeytan bozulmayı ve fesadı ifade eder. Ne var ki, yaradılışa müdahalenin başlama sınırını ve ölçüsünü belirlemek de zordur. Bu değiştirme Kuranı Kerim'de 'tebdil' ve 'tağyir' kelimeleriyle anlatılır. Tebdil, 'bedel' kökünden gelir ve bir şeyin yerine, ondan bedel bir başka şeyi koymayı ifade eder. Tağyir ise, bir şeyi başka bir şey/ğayr olacak şekilde kendi içinde değiștirme demektir. "Allah'ın yaratışında tebdil olmaz, doğru din budur..." (erRûm 30/30). "İnsanlara Allah'ın yaratışını değiștirmelerini söyleyen şeytandır" (en-Nisâ 4/119), anlamındaki ayeti kerimeler her iki değiştirmeyi de yasaklamaktadır.

Organ nakliyle duygu değişimi ve genetik değişim olabileceği söylenmektedir. Son zamanlarda bu konuda bilimsel makaleler yayımlanmaya başladı. (Bkz. https://www.dailymail.co.uk/news/article-7769433/Nevadamans-DNA-changes-bone-marrow-transplant-replaced-German-donor.html.

Ayrica: https://tr.euronews.com/amp/2019/12/14/ilik-nakli-olan-kisininsadece-kanindaki-degil-spermindeki-dna-da-degisti)

Organ naklinin de genetik müdahalenin de Kur'an-ı Kerim'in yasakladığı değiștirme olması kuvvetle muhtemeldir.

\section{Maslahat ve Mefsedet Prensibi Açısından Organ Nakli}

Kesin naslarla hükmü belli olmayan böyle konularda hüküm vermek için fakihlerin kâr-zarar, ya da maslahat-mefsedet hesabı yaptıklarını da biliyoruz. Bu da İslam'ın doğru anlaşılmasının bir metodudur. Sâfi maslahata izin verilir, sâfi zarar yasaklanır. İkisi birlikte bulunan konularda takdir yapılır ve hangi taraf galipse ona göre hüküm verilir. Çünkü İslam bütünüyle maslahatın temininden ibarettir.

Bu durumda günümüzdeki âlimlerin çoğu organ nakli için genel olarak caiz demiş olsalar bile, organ nakli uygulamalarının pek çok çeşidinde tarafsız bir ölçüm yapmak mümkün olabilse, nakil yapmadaki toplam mefsedetin toplam maslahattan fazla olma ihtimali vardır.

Muhtaç insanların organlarını satmak zorunda kalmaları, bu ișin mafyasının küçümsenmeyecek boyutlarda olması, yapılan hatalar, az da olsa verilen kasıtlı kararlar ve organ verenlerde oluşacak zararlar hesaba katıldığında meselenin mefsedet tarafının galip geleceği söylenebilir.

\section{Organ naklinin hükmüyle ilgili sonuç sadedinde neler söylersiniz?}

Sonuç olarak bu genel cevaz fetvasıyla hareket edip, organ naklinin haram olduğunu şimdilik söyleyemesek bile ihtiyatı elden bırakmamak ve aksi ihtimalleri de sürekli hesaba katmak gerekir diye düşünüyoruz. Çünkü insan cansız bir makine değildir ve o sadece fiziki varlığıyla da insan değildir. Elbette 
bugün bu teknolojiyi uygulayanlar ya da savunanlar da bunun insana bir değer verme ifadesi olduğunu söylüyorlar. Ama değer ölçümünün keyfiyeti ya da parametreleri önemlidir ve daha iyi olan da her zaman biraz daha fazla yaşamak olmayabilir.

0 halde her çeşidiyle organ naklinin hala yeni bir mesele sayılması gerektiğini söyleyebiliriz. Daha uzun vadede ortaya çıkacak komplikasyonlarının şimdiden bütünüyle belli olduğunu iddia edemeyiz.

Kısaca organ naklinin bir hayat iksiri olarak görülmesi için hem tıbben hem de dinen zaman henüz erkendir.

\section{Fanteziler de düşünülmelidir}

Organ naklinin dini hükmünü konuşanların aşağıdakilere benzer fantezilerden de söz ettiklerine şahit oluruz. Bunlar şimdilik birer fantezi olsa da düşünce kanallarını açmaya yarayabilirler:

Mesela, konunun imanla alakasını kurup; gayrimüslimden organ almanın bedene temiz olmayan bir parçanın eklemlenmesi, ya da ona organ vermenin küfrün devamını sağlama anlamına gelmesi gibi faraziyeleri söz konusu edenler olmuştur, ancak bunun tutarlı olmadığı açıktır, şöyle ki:

Bir müslümanın gayrimüslimden organ alması ya da ona organ vermesi diğerinden farklı değildir. Çünkü iman etmeyen, insanın organları değil, kendisidir. Bir gayrimüslime organ vermeyi küfrün devamına yardım gibi düşünmenin de anlamı yoktur. Aksine bu, o insanın yaşamasını sağlayarak, onun iman etme ihtimalini artırma olarak da değerlendirilebilir. Ayrıca hatırlamak gerekir ki, organ nakli için en önemli delil olarak görülen ayeti kerimede Allah, bir canı ölümden kurtarmak suretiyle onu yaşatanın bütün insanları diriltmiş gibi olacağını söylerken, Müslüman ya da kâfir ayırımı yapmamıștır.

İnsanın bunca değerli sayılmasına karşılık organlarının nasıl alınabileceği itirazı için de denebilir ki, elbette hayatta olan insan ölenden daha değerlidir. Çünkü insanın değeri Allah'a olan kulluğu, yani takvası iledir. Bu da hayatta iken yapılabilen bir şeydir. Ancak ölenin bu değerinde azalma olduğunu söylemek de ispatı zor bir iddiadır.

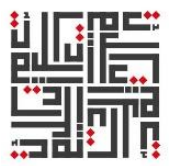

